\title{
Profil Sebaran Burung di Pohon Peneduh Sepanjang Jalan MT. Haryono dan Tlogomas Kecamatan Lowokwaru Kota Malang
}

\section{Profile Distribution of Birds in Shade Tree along the MT. Haryono Road and Tlogomas Subdistrict Lowokwaru, Malang}

\author{
M. Bachri $\left.{ }^{1 *}\right)$, Hasan Zayadi $\left.{ }^{2 * *}\right)$, Ari Hayati ${ }^{3}$ \\ ${ }^{123}$ Jurusan Biologi Fakultas Matematika Ilmu Pengetahuan Alam (FMIPA), Universitas Islam Malang, Indonesia
}

\begin{abstract}
ABSTRAK
Burung merupakan satwa liar yang mudah ditemukan hampir di daerah yang memiliki vegetasi. Dalam hal ini burung merupakan salah satu bioindikator suatu daerah untuk mengetahui suatu perubahan suatu lingkungan dan mencerminkan stabilitas habitat. Penelitian ini bertujuan untuk mengetahui jenis dan persebaran distribusi burung pada pohon peneduh di jalan M.T. Haryono dan Tlogomas Kota Malang. Penelitian menggunakan metode jelajah atau deskriptif-ekploratif secara langsung di lapangan dengan mencatat data koordinat jenisjenis burung yang ditemukan di pohon peneduh sepanjang jalan raya dengan menggunakan GPS. Ditemukan empat jenis burung yaitu emprit/ bondol jawa (Lunchura leucogastroides) sebanyak 102 titik persebaran, burung gereja (Passer domesticus) sebanyak 18 titik persebaran, burung cucak kutilang (Pycnonotus aurigaster) sebanyak 11 titik persebaran dan spesies burung tekukur biasa (Streptopelia chinensis) 8 titik persebaran. Dengan jumlah keseluruhan yaitu 139 titik persebaran dari semua pohon peneduh yang ada. Berdasarkan penelitian dihasilkan frekuensi pada pagi hari yaitu $66,2 \%$ dan pada sore hari diketahui $25,9 \%$. Pohon peneduh yang paling sering ditemukan oleh burung adalah pohon Trembesi dan Mahoni.
\end{abstract}

Kata kunci: Distribusi spasial burung, pohon peneduh, jalan raya

\begin{abstract}
The bird is a wildlife that is easily found in almost area vegetation. In this case the bird is one of the bioindikator an area to know a change an environment and reflect the stability of the habitat. This research aims was to know the type and spread of the distribution of birds on a shade tree in the M.T. Haryono road and Tlogomas Malang. Research used the method of cruising or descriptive-explorative directly in the field with the recorded data coordinates the types of birds that are found in shade trees along the road by using GPS. The study found four types of bird i.e. emprit/Javan Munia (Lunchura leucogastroides) as much as 102 points of distribution, sparrows (Passer domesticus) as many as 18 point spread, bird cucak kutilang (Pycnonotus aurigaster) a total of 11 points distribution and species of birds spotted Dove (Streptopelia chinensis) 8 point spread. With the number of whole namely 139 point distribution of all trees shade. Based on studies generated frequency in the morning is 66, 2\% and in the afternoon is 25, 9\%. The shade tree most frequently was found by the bird are the trees of Trembesi and Mahoni.
\end{abstract}

Keywords: spatial distribution of birds, shade trees, road

\footnotetext{
*) M. Bachri Jurusan. Jurusan Biologi FMIPA UNISMA. Jl. MT. Haryono 193, Malang 65144 Tlp. 083122854540 email: mbachri92@gmail.com

**) Hasan Zayadi, S.Si., M.Si, Jurusan Biologi FMIPA UNISMA. Jl. MT. Haryono 193, Malang 65144 Tlp. 085649548913 email: hasanzayadi@unisma.ac.id
}

Diterima Tanggal 22 Februari 2018 - Diterbitkan Tanggal 25 Januari 2020 


\section{Pendahuluan}

Kota Malang merupakan daerah otonom dan Kota besar kedua setelah Kota Surabaya di Jawa Timur. Malang tidak lepas dari permasalahan sosial dan lingkungan yang semakin buruk kualitasnya [1]. Penyusun vegetasi diperkotaan adalah pohon peneduh jalan. pohon peneduh jalan memliki dua fungsi yaitu sebagai estetika dan ekologis. Salah satu fungsi ekologis tanaman peneduh jalan adalah mengakumulasi bahan pencemaran [3].

Penelitian untuk habitat hewan dan habitat tumbuhan itu sendiri juga sangat berpengaruh besar tehadap ekosistem. Hasil penelitian menunjukkan bahwa diversitas tumbuhan juga berpengaruh terhadap diversitas hewan dalam suatu ekosistem [6], kehilangan spesies tumbuhan sangat mengganggu jaring-jaring makanan dalam ekosistem [7].

Burung merupakan salah satu satwa liar yang penyebarannya ditemukan setiap lingkungan bervegetasi. Burung mempunyai pesebaran tinggi dan tersebar keberbagai wilayah serta jumlahnya mencapai 9.000 jenis [8]. Jumlah jenis burung di Indonesia tercatat 1.666 jenis [9] yang mampu hidup di hutan yang lebat hingga ke perkotaan padat penduduk. Penyebaran yang luas tersebut menjadikan burung sebagai salah satu sumber kekayaan hayati Indonesia yang potensial. Di samping berperan dalam keseimbangan ekosistem burung dapat menjadi indikator perubahan lingkungan.

Penelitian mengenai burung penting dilakukan karena jika suatu areal memiliki kelimpahan burung yang tinggi, maka dapat menjadi salah satu indikator bahwa kondisi lingkungan baik [10]. Hal ini dikarenakan burung memiliki kemampuan untuk menyebarkan biji, membantu penyerbukan, predator alami satwa lain, dan lain-lain. Burung dalam melakukan aktivitasnya membutuhkan habitat. Sebagai salah satu komponen lingkungan, burung dapat dimanfaatkan langsung atau tidak langsung sebagai bioindikator lingkungan. Beberapa penelitian burung dapat digunakan untuk mendeteksi perubahan lingkungan serta dapat mencerminkan stabilitas habitat [11].

Penelitian terkait pohon peneduh dilakukan oleh [5] pohon peneduh yang ditemukan sebanyak 18 spesies dengan total pohon sebanyak 193 Individu. Pohon Peneduh yang paling banyak tersebar di sepanjang jalan adalah pohon Angsana (Pterocarpus indicus) dengan jumlah individu 75 individu, pohon Mahoni (Swietinia macrophylla) 48 individu, pohon kersen (Muntingia calabura) dan Trembesi (Albizia saman). Sedangkan penelitian terkait sebaran burung belum dilakukan dikawasan tersebut.

Berdasarkan fenomena di atas, maka diperlukan suatu penelitian dan kajian sebaran jenis burung di sepanjang jalan raya M.T Hayono dan Tlogomas Kecamatan Lowokwaru Kota Malang. Wilayah ini merupakan kawasan atau jalur utama menuju wisata kota Batu dan banyaknya kendaraan bermotor yang melewati kawasan ini. Selain itu database terkait data persebaran jenis burung-burung peneduh pinggir jalan masing belum dilakukan penelitian sehingga peneliti tertarik untuk melakukan penelitian terkait distribusi spasial jenis-jenis burung di pohon peneduh yang ada di kawasan tersebut.

Tujuan penelitian mengetahui jenis-jenis burung apa saja yang ditemukan di pohon peneduh dan distibusi spasial jenis-jenis burung yang ditemukan di pohon peneduh sepanjang jalan raya M.T. Haryono dan Tlogomas kecamatan Lowokwaru Kota Malang

\section{Material dan Metode}

\section{Bahan dan Alat}

Bahan dan alat yang digunakan pada penelitin ini adalah: teropong binokuler, anemometer dan termometer, GPS, kamera DSLR, ATK.

\section{Metode}

Rancangan penelitian: Penelitian ini dilakukan dengan metode deskrptif-ekploratif secara langsung di lapangan dengan mencatat data koordinat jenis-jenis burung pohon peneduh di sepanjang jalan raya dengan menggunakan GPS. Hasil dari eksplorasi tersebut didapatkan data spasial koordinat pohon peneduh, sehingga dihasilkan peta distribusi spasial burung di pohon peneduh. Pengambilan sampel 
dilakukan pada dua lokasi yang berbeda yaitu jalan M.T. Haryono dan jaln Tlogomas. Dilakukan menggunakan cara pengamatan dilokasi pengamatan dipohon-pohon peneduh, pengamatan dilakukan dengan mnggunakan metode penjelajahan (cruising method) (Bibby, 1992). Penjelajahan dilakukan dengan berjalan kaki. Setiap titik pengamatan ditandai dengan GPS untuk didapatkan koordinatnya. Disamping itu dicatat faktor abiotik yaitu suhu dan kecepatan angin dilokasi penelitian.

\section{Cara Kerja}

Tahapan Penelitian pada Persiapan: Beberapa alat yang disiapkan adalah GPS untuk menandai titik koodinat persebaran burung, kamera digital untuk mendokumentasikan burung yang ditemukan, peta google earth dan lembar kerja untuk mencatat hasil penelitian, teropong binokuler untuk melihat burung dalam jarak kejauhan, termometer untuk mengukur suhu dan anemometer untuk mengatur kecepatam angin. Dan bahannya yaitu burung yang diamati saat pengamtan di lapangan

Teknik pengumpulan data pada pembuatan peta lokasi: Titik koordinat didapatkan dari hasil pengamatan burung dilapangan dengan menggunkan GPS, kemudian dilakukan overlay dari layar ke dalam aplikasi Google Earth . Hasil yang didapatkan adalah peta distibusi jenis burung.

Identifikasi Burung: Identifikasi jenis-jenis burung dengan cara pengamatan dilokasi yang ditemukan dengan menggunakan buku identifikasi burung yaitu burung-burung di Jawa dan Bali [11] dan refrensi pendukung lainnya.

\section{Hasil dan Diskusi}

\section{Hasil Penelitian}

Hasil frekuensi analisis persebaran jenis burung di lokasi penelitian dapat dilihat dari dari gambar 7 diatas pada pohon peneduh di sepanjang jalan M.T. Haryono dan Tlogomas yaitu burung Emprit/bondol jawa (Lonchura leucogastroides) lebih sering dijumpai di sepanjang jalan tersebut ditemukan di beberapa pohon peneduh sebanyak 102 titik persebaran. Kehadiran spesies ini pada pohon peneduh diduga untuk mencari makan, dikarenakan spesies ini merupakan burung pemakan biji-bijian. Paling dominan burung emprit atau bondol jawa yang bertengger hampir semua pohon peneduh yaitu pohon angsana, mahoni, mangga, palem, dadap merah, waru, kiara payung dan trembesi.

Burung gereja (Passer domesticus) dimana diketahui sebanyak 18 titik koordinat paling dominan burung gereja bertengger di pohon peneduh yaitu dadap merah, mahoni, beringin dan trembesi. Burung cucak kutilang (Pycnonotus aurigaster) 11 titik persebaan dan burung tersebut paling dominan bertengger di pohon mahoni, angsana, trembesi, mangga dan palem. Dan yang keempat yaitu Spesies burung tekukur biasa (Streptopelia chinensis) dengan jumlah 8 titik persebaran dan spesies ini paling dominan bertengger di pohon peneduh mahoni, angsana dan trembesi.

Tabel 1. Jenis-jenis burung pada pohon peneduh disepanjang jalan M.T. Haryono dan Tlogomas

\begin{tabular}{|l|l|l|l|l|}
\hline Nama Lokal & Ordo & Familia & Genus & Nama ilmiah \\
\hline Emprit & Passeriformes & Lonchuridae & Lonchura & Lonchura leucogastroides \\
\hline Gereja & Passeriformes & Passeridae & Passer & Passer domesticus \\
\hline Cucak kutilang & Passeriformes & Pycnonotidae & Pycnonotus & Pycnonotus aurigaster \\
\hline Tekukur biasa & Columbiformes & Columbidae & Streptopelia & Streptopelia chinensis \\
\hline
\end{tabular}



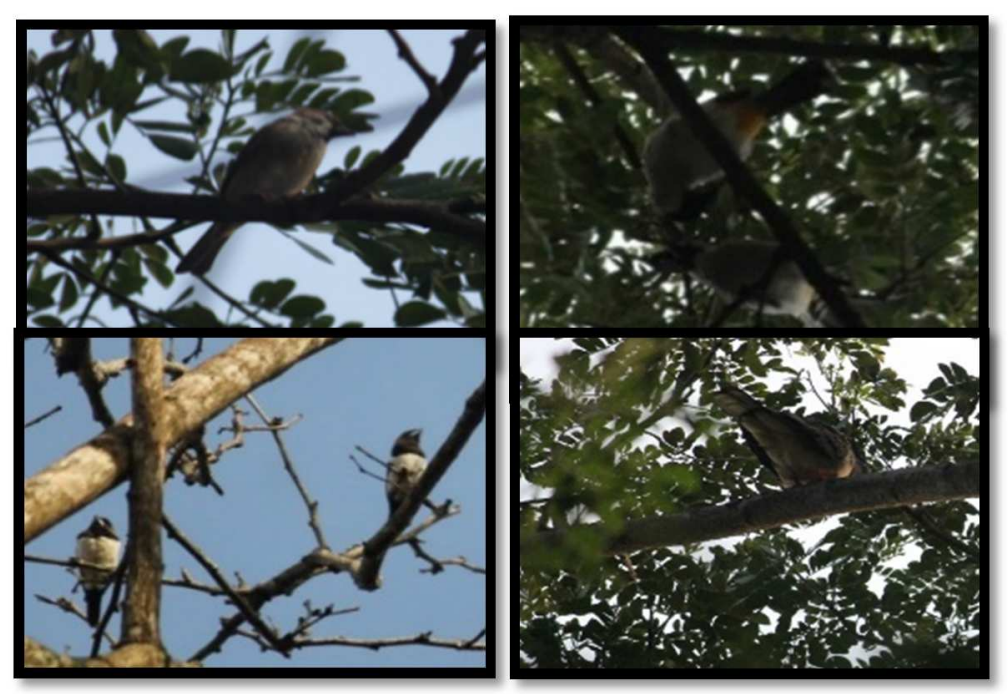

Gambar 1. Burung yang ditemukan

a) Emprit, b) Gereja, c) Cucak Kutilang, d) Tekukur Biasa

Menurut [13] tingginya frekuensi relatif burung menujukkan burung adaptasi yang baik terhadap kondisi lingkungan di sekitarnya dan terhadap keberadaan manusia. Dan spesies bondol jawa dan gereja jenis burung yang mudah dijumpai di daerah perkotaan. Dan semakin rendahnya frekuensi maka mendapatkan hasil yang sebaliknya yaitu adaptasi yang buruk terhadap kondisi lingkungan di sekitarnya dan terhadap keberadaan manusia.

\section{Pembahasan}

Hasil pengamatan yang dilakukan dapat dilihat pada gambar 3 di atas bahwa pada pagi didapatkan persentase sebesar $66,2 \%$ dan pada sore hari diketahui sebasar 25,9\%. Hal tesebut disebabkan persebaran burung di pagi hari diketahui suhu rata-rata yaitu sekitar $25,5^{\circ} \mathrm{C}$ dan kecepatan angin $0,74 \mathrm{~m} / \mathrm{d}$ persebaran burung lebih banyak dibandingkan dengan diwaktu sore hari yaitu dengan suhu rata-rata suhu $28^{\circ} \mathrm{C}$ dan kecepatan angin sebesar $0,675 \mathrm{~m} / \mathrm{d}$. Hal ini diduga karena pada pagi hari burung pada waktu tersebut memulai aktifitas harinya yaitu untuk mencari makan. Sedangkan pada sore hari burung sedang istirahat atau melakukan aktifitas lainnya seperti bertengger atau berdiam diri disuatu tempat yang lebih aman dan kembali kesarangnya.

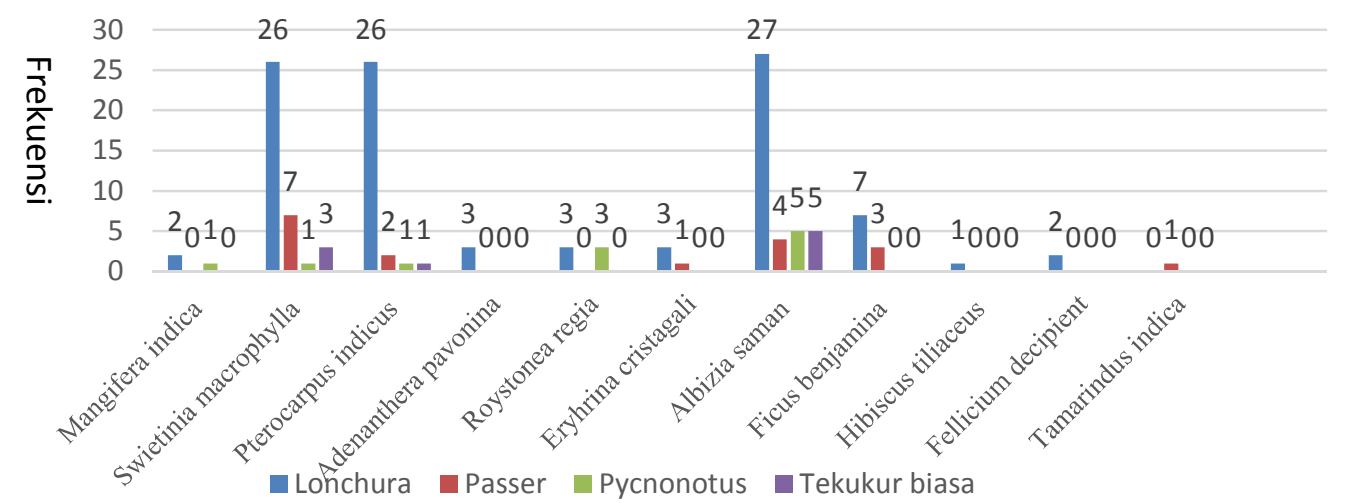

Gambar 2. Frekuensi hasil persebaran burung pada pohon peneduh di jalan M.T Haryono dan Tlogomas 


\section{e-Jurnal Ilmiah BIOSAINTROPIS (BIOSCIENCE-TROPIC) Volume 5/ No.: 2 / Halaman 17 - 23 / Januari Tahun 2020 ISSN : 2460-9455 (e) - 2338-2805(p)}

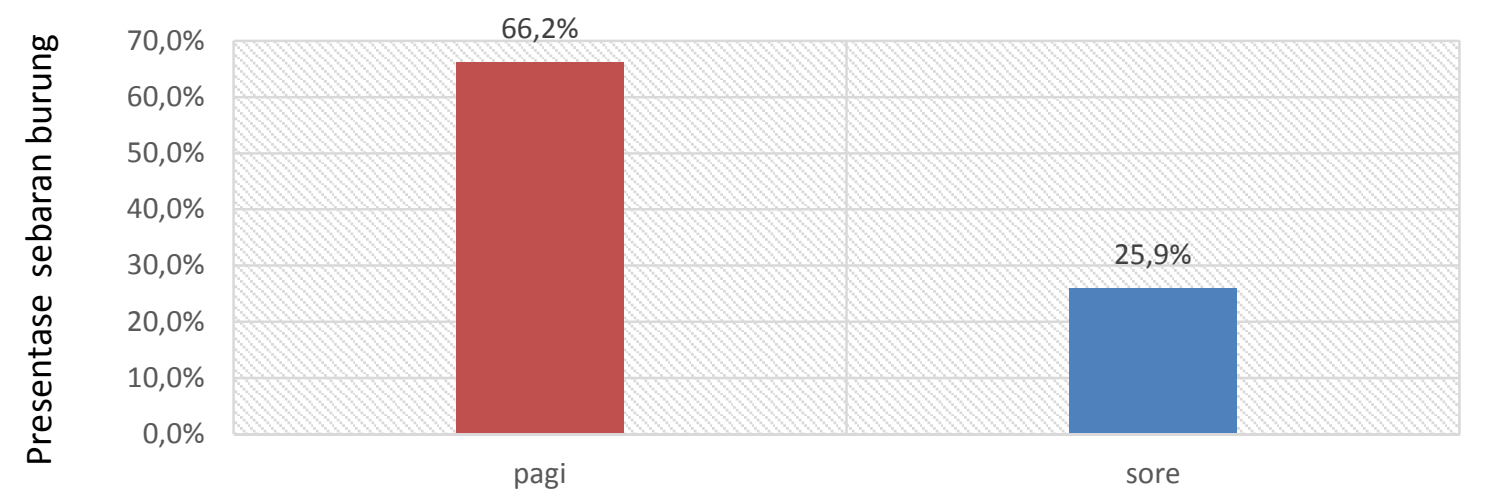

Gambar 3 : Persentase sebaran burung pada pagi dan sore hari di pohon peneduh disepanjang jalan M.T Haryono dan Tlogomas

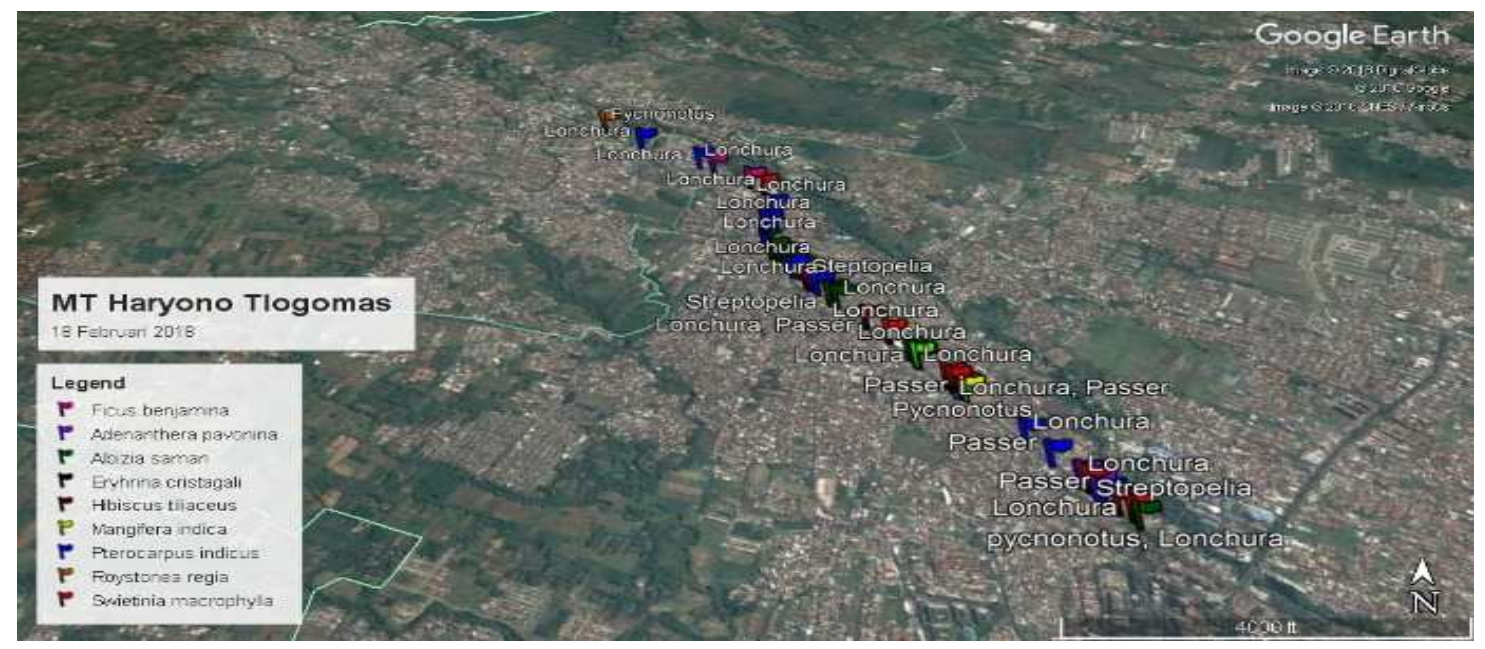

Gambar 4. Peta persebaran burung di sepanjang jalan MT Haryono Tlogomas (29-30 januari 2018)

Menurut [13] kehadiran beberapa jenis burung dipengaruhi oleh faktor ketersediaan makanan, meskipun secara tidak langsung beberapa jenis-jenis burung juga membutuhkan vegetasi sebagai tempat bersarang. Sehingga ketersediaan makanan dan tempat bersarang merupakan habitat yang mendukung bagi burung. Selanjutnya faktor-faktor yang mempengaruhi pemilihan habitat dipengaruhi oleh struktur morfologi, perilaku, kesuksesan mempertahankan makanan dan tempat berlindung. Rangsangan pemilihan habitat kemungkinan besar 8 datang dari komponen-komponen pendukung suatu wilayah, tempat pencarian makanan atau bersarang, dan atau kehadiran spesies lain. Setiap faktor dapat bekerja terpisah, sebagai satu kesatuan sistem yang saling mendukung atau bekerja secara sienergi.

Sebaran burung pohon peneduh di sepanjang jalan MT. Haryono dan Tlogomas yang paling sering ditemukan adalah burung Emprit di pohon peneduh Beringin, Mahoni, Angsana, Mangga, Saga, Trembesi, Dadap Merah, Waru, Palem dan Kiara Payung. burung Gereja yaitu di pohon peneduh Mahoni, Saga, Trembesi dan Dadap merah. burung Tekukur yaitu di pohon peneduh Mahoni, Angsana dan Trembesi. Bururng Cucak Kutilang di pohon Trembesi dan Palem. Jadi pohon yang banyak ditemukan di hinggapi burung adalah Trembesi dan Mahoni. 


\section{e-Jurnal Ilmiah BIOSAINTROPIS (BIOSCIENCE-TROPIC) Volume 5/ No.: 2 / Halaman 17 - 23 / Januari Tahun 2020 ISSN : 2460-9455 (e) - 2338-2805(p)}

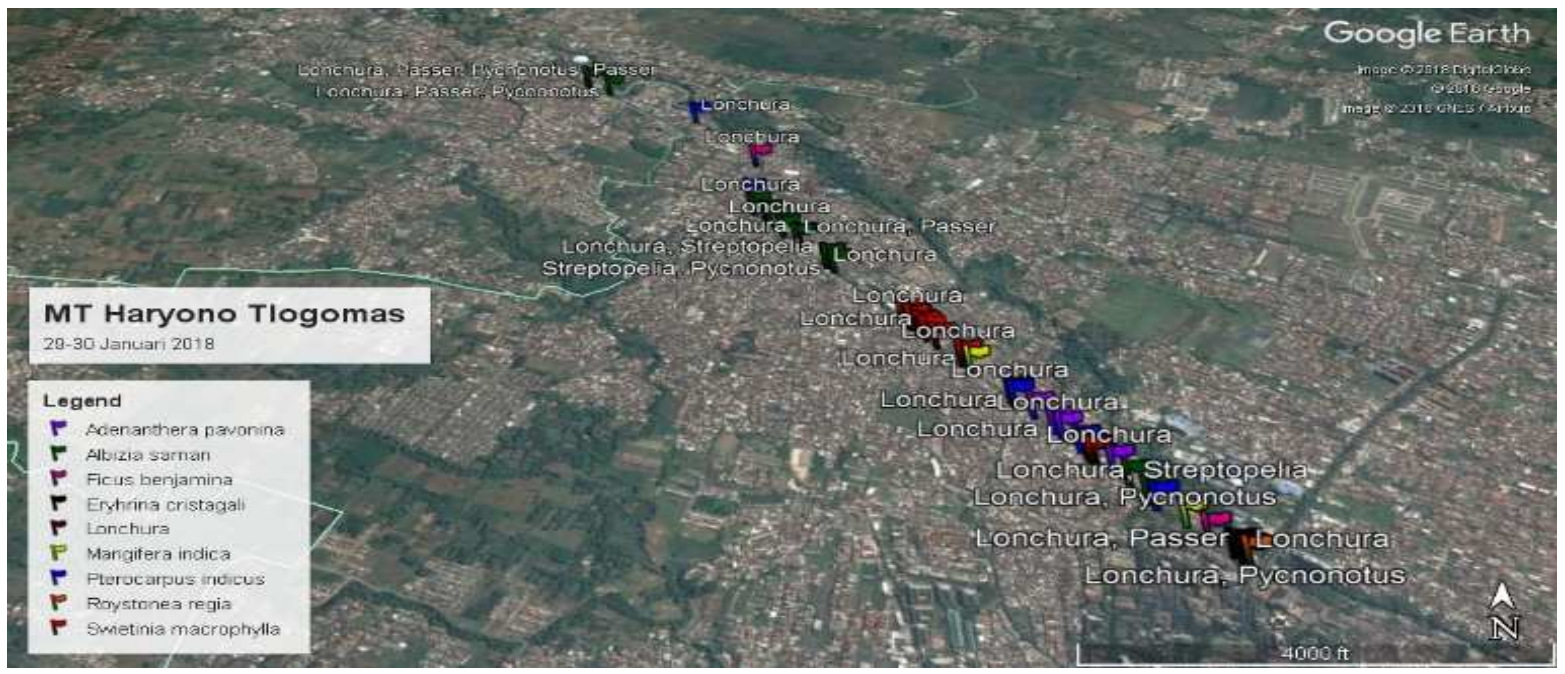

Gambar 5. Peta persebaran burung di sepanjang jalan MT Hayono Tlogomas (18 -02- 2018)

Persebaran burung di lokasi penelitian yaitu burung Emprit lebih sering dijumpai di sepanjang jalan tersebut ditemukan pohon peneduh sebanyak 102 titik persebaran. Burung Gereja diketahui sebanyak 18 titik persebaran. burung Cucak Kutilang (Pycnonotus aurigaster) di 11 titik persebaan. Burung tekukur biasa (Streptopelia chinensis) 8 titik persebaran.

\section{Kesimpulan}

Distribusi spasial aves pada pahon penduh di sepanjang jalan MT. Haryono dan Tlogomas dapat di ketahui hasil 2 Ordo 4 familia 4 jenis yaitu burung emprit/bondol jawa (Lonchura leucogastroides), Gereja (Passer domesticus), Cucak kutilang (Pycnonotus aurigaster) dan Tekukur biasa (Streptopelia chinensis).

Distribusi penyebaran burung pohon peneduh yaitu burung bondol jawa lebih sering dijumpai sebanyak 102 titik persebaran yaitu di pohon angsana, mahoni, mangga, palem, dadap merah, randu dan trembesi. Burung gereja sebanyak 18 titik persebaran yaitu di pohon dadap merah, mahoni, beringin dan trembesi. Burung cucak kutilang 11 titik persebaran yaitu di pohon mahoni, trembesi dan palem dan burung tekukur 8 titik persebaran yaitu di pohon peneduh mahoni, angsana dan trembesi.

Persebaran burung di pagi didapatkan persentase sebesar 66,2\% dan pada sore hari sebasar 25, 5 $\%$. Dalam hal ini juga dipengaruhi oleh faktor abiotik yaitu suhu dan kecepatan angin. Hal tesebut oleh beberapa faktor abiotik yaitu suhu dan kecepatan angin dengan ini persebaran burung di pagi hari diketahui suhu rata-rata yaitu sekitar $25,5^{\circ} \mathrm{C}$ dan kecepatan angin $0,74 \mathrm{~m} / \mathrm{d}$ persebaran burung lebih banyak dibandingkan waktu sore hari dengan suhu rata-rata suhu $28^{\circ} \mathrm{C}$ dan kecepatan angin sebesar 0 , $675 \mathrm{~m} / \mathrm{d}$.

\section{Daftar Pustaka}

[1] Pemerintah kota Malang. 2013. Rencana pembangunan jangka menengah kotam Malang. Malang

[2]Wania, A. 2012. Analyzing the influence of different street vegetation on taffic-induced paticle dispersion using microscale simulations. Journal of environmental management, 94(1), PP.91-101. Available at: http://dx.doi.org/10.1016/j.jenvman.2011.06.036. 
[3]Santoso, S., Lestari, S dan Samiyarsih, S., 2012. Inventaiasasi tanaman peneduh jalan penyerab timbal di Purwokerto. In semina berkelanjutan II. Univesitas Jendral Sudirman Purwokerto. pp. 197-203

[4] Shan, Y. 2007. Effects of vegetation status in urban green spaces on paticle emoval in a street canyon atmosphere. Acta ecoogica sinica, 27(11), pp. 4590-4595.

[5]Zayadi, H. dan Ari, H. 2017. Distribusisi spasial pohon peneduh di jalan raya Lowokwaru Kota Malang dengan Aplikasi GIS. Universitas Islam Malang. Malang

[6] Sujatnika, P.J., Sohartono, T. R., Crosby, M. J. dan Maraiastutik, A. 1995. Melestarikan keanekaagaman hayati Indonesia pendekatan daerah burung endemik. PHP A/ Birdlife internasional Indonesia progamme. Jakarta.

[7]Zayadi, H., Hakim, L dan Setyoleksono, A. 2013. Composition and diversity of soil athopods of Rajegwesi Meru Betiri National park. Journal of tropical life science, 3(3), pp 166-171.

[8] Perrins, C,M. \& T.R, Birckie. nd. Avian ecology. Birckie \& sons Ltd. New york

[9]Susanti. 2014. Indonesia miliki 1666 jenis burung dan terkaya jenis endemik [internet] diunduh 2014 Nov 16: Bogor ID. Tersedia pada http://www.burung.org/indek.php?option.com con. Tent \&view article id. 920 \& catid $28 \&$ itemid 75

[10]Arief. 2003. Hutan mangrove fungsi dan manfaatnya. Kaisius. Yogyakata.

[11]MacKinnon, J., K. Philipps, dan B. van Balen. 1999. Burung-burung di Sumatera, Jawa, Bali, dan Kalimantan (Termasuk Sabah, Sarawak, dan Brunei Darussalam). Puslitbang Biologi LIPI dan BirldLife Indonesia. Bogor.

[12] Summers, S, D. 2016. Eurasian tree sparrow (Passer montanus) handbook of the birds of the world alive. Lynxedicions. Bacelona

[13] Cody, M.L. 1985. Habitat Selection in Bird. Academic Press Inc, London. 